\title{
Lack of association between human Oxoguanine Glycosylase 1 (hOGG1) S326C polymorphism and the risk of gastric cancer: a meta-analysis
}

\author{
R. DING*, D. J. CHEN, S. L. LIN \\ School of Public Health, Anhui Medical University, Hefei, China \\ *Correspondence: kilthy11@yahoo.com
}

Received October 21, 2011 / Accepted November 22, 2011

\begin{abstract}
Results from published studies on the association of Human Oxoguanine Glycosylase 1 (hOGG1) S326C genetic polymorphism with the risk of gastric cancer are inconsistent. We performed a meta-analysis to summarize the possible association. Eleven case-control studies including 2168 cases and 4058 controls were identified from electronic databases (Pubmed, Elsevier Science Direct, Chinese National Knowledge Infrastructure (CNKI), Chinese Biomedical Literature Database (CBM), and the Chinese database, Wanfang). No significant association between hOGG1 S326C genetic polymorphism and risk of gastric cancer was observed in the overall analysis. In the stratified analysis based on ethnicity, still no significant association was observed in Europeans, Asians, or Brazilians. This meta-analysis provided evidence that hOGG1 S326C genetic polymorphism was not associated with increased risk of gastric cancer. However, additional studies with large sample size and better study designs are warranted to verify our finding.
\end{abstract}

Key words: hOGG1, polymorphism, gastric cancer, meta-analysis

Gastric cancer is the second most common cancer worldwide, it is estimated that gastric cancer accounted for about 738,000 deaths in 2008 globally [1]. Like other malignancies, the etiology of gastric cancer is multifactorial and incompletely understood [2]. Several epidemiological studies have confirmed the risk factors of gastric cancer which includes low consumption of fresh fruits and vegetables, high consumption of salty food, smoking, and Helicobacter pylori (H. pylori) infection [3-5]. Although just how the biological mechanisms underlying these factors are involved in gastric cancer development is not clearly understood, oxidative DNA damage caused by reactive oxygen species (ROS) is believe to play an important role.

Reactive oxygen species (ROS) is demonstrated to induce mutations in many types of DNA, proto-oncogenes, tumor suppressor genes, and other genes important for induction and progression of cancer [6]. The consumption of several kinds of food such as red meat, alcohol, fat, may induce the generation of ROS, which may have effect on gastric mucosa [7]. On the other hand, the infection of $\mathrm{H}$. pylori was demonstrated to result in additional ROS formation, and may induce apoptosis and DNA damage in host gastric epithelial cells [8-11].
One of the most common lesions formed by ROS modifications is 8-Hydroxy-2'-deoxyguanosine (8-OHdG). 8 -OHdG is believed to be highly mutagenic because of its propensities to mispair with adenine during DNA replication and to cause ultimately GC to TA transversion [12-13]. A specific DNA glycosylase/apurinic (AP) lyase, human 8-oxoguanine glycosylase 1 (hOGG1), has an activity to remove 8 -OHdG from DNA as a part of the base excision repair pathway [14-15].

The human OGG1 gene is reported to have several kinds of mutations, of which a Ser/Cys substitution in exon 7 is highly prevalent[16-17]. Studies demonstrated that the hOGG1 protein encoded by the wild-type CC genotype exhibited substantially higher DNA repair activity than that encoded by CG or GG genotype. Some studies have suggested that the hOGG1 S326C polymorphism is associated with increased risk for lung [18], orolaryngeal [19], bladder [20] as well as gallbladder cancers [21]. There are also a number of case-control studies performed to investigate the association of hOGG1 S326C polymorphism with gastric cancer, but the results remain inconclusive and contradictive. Several reasons such as relative small sample size, different ethnic background may partially cause this discordance. Therefore, we performed the present meta-analysis to obtain a more precise estimation of the association. 


\section{Materials and Methods}

Study Selection. All studies that examined the association between hOGG1 S326C genetic polymorphism and gastric cancer were carefully selected. Data were collected from the following databases: Pubmed, Elsevier Science Direct, Chinese National Knowledge Infrastructure (CNKI), Chinese Biomedical Literature Database (CBM), and the Chinese database, Wanfang. The key words were as follows: ("gastric cancer "OR "stomach cancer"), ("OGG1" OR "hOGG1" OR "OGG” OR "8-Oxoguanine DNA glycosylase 1"), and ("polymorphism" OR "variation" OR "mutation" OR "SNP"). In the CNKI, CBM, and Wanfang, crossponding Chinese characters of the keywords were used for searching. There was no restriction on language.

A study was included in the current meta-analysis if (1) it was published up to Oct 2011, (2) if it was a case-control study, and (3) or it was about hOGG1 S326C polymorphism and risk of gastric cancer. Studies reported the results on different subpopulations were treated as separate studies. When there were multiple publications from the same population, only the latest study was included.

An independent Pubmed search by DR, an independent Elsevier Science Direct search by CDJ, and independent CNKI, CBM, and Wanfang searches by LSL were performed using the same criteria. The abstracts were carefully reviewed to determine if they met the eligibility criteria. References in the studies were also reviewed and hand-searched to obtain additional studies.

Data Extraction. Two investigators (DR and LSL) extracted data independently and in duplicate with the standard protocol and the results were reviewed by a third investigator (CDJ). Disagreements were discussed and resolved with consensus. From each study, information such as the first author's last name, year of publication, country of origin, numbers of cases and controls, sources of controls, genotyping method, and genotypes and allele frequency information from genetic polymorphisms were extracted.

Statistical analysis. The meta-analysis was performed by using Stata 11.0 software (Stata Corporation College Station, TX, USA). Hardy-Weinberg equilibrium (HWE) in control groups of each study were assessed using goodness-of-fit test ( $\chi^{2}$ of Fisher's exact test). The association between gastric cancer risk and hOGG1 S326C polymorphism was estimated for each study by crude odds ratios (ORs) and their 95\% confidence intervals (CIs). We estimated the risk first for the variant homozygous GG genotype, compared with the wildtype homozygous CC genotype, and then for the dominant model (GG+CG versus CC) and recessive model (GG versus $\mathrm{CG}+\mathrm{CC}$ ), respectively. Stratified analysis was performed based on the region (Asian, European, and American).

Heterogeneity among studies was examined with $\chi^{2}$ test-based $Q$ statistic [22]. If there was no statistical heterogeneity among studies $(P>0.10)$, the ORs and $95 \% \mathrm{CI}$ were estimated by MantelHaenszel's method in a fixed-effect model [23]. Otherwise, the ORs was obtained by DerSimonian-Laird method in a randomeffect model [24]. The effect of heterogeneity was also measured by: $I^{2}=100 \% \times(\mathrm{Q}-\mathrm{df}) / \mathrm{Q}$ to assess the extent of between-study heterogeneity [25]. The pooled OR was performed by weighting individual ORs by the inverse of their variance, and the significance of the pooled OR was determined by the $z$ test.

Evaluation of publication bias. Publication bias was investigated with the funnel plot, in which the standard error of $\log (\mathrm{OR})$ of each study was plotted against its OR value. Funnel plot asymmetry was further assessed using Egger's linear regression test using Stata 10.0 software [26-27]. The p-value of Egger's linear regression test less than 0.05 was considered representative of statistically significant publication bias.

Table 1. Main characteristics of the studies included in the meta-analysis

\begin{tabular}{|c|c|c|c|c|c|c|c|c|}
\hline \multirow[t]{2}{*}{ Study } & \multirow[t]{2}{*}{ Year } & \multirow[t]{2}{*}{ Ethnicity } & \multirow[t]{2}{*}{ Source of control } & \multirow[t]{2}{*}{ Matched factor } & \multicolumn{2}{|c|}{$\begin{array}{c}\text { Sample size (frequency of } \mathrm{G} \\
\text { allele, \%) }\end{array}$} & \multirow[t]{2}{*}{$\begin{array}{l}\text { OR }(95 \% \text { CI for } \\
\text { G vs. C allele) }\end{array}$} & \multirow[t]{2}{*}{$\begin{array}{l}P \text {-value of } \mathrm{HWE}^{\mathrm{b}} \\
\text { in controls }\end{array}$} \\
\hline & & & & & case & control & & \\
\hline Capella G & 2008 & European & Population based & $\begin{array}{l}\text { Centre, sex, age, date of } \\
\text { blood collection }\end{array}$ & $438(20.66)$ & $1026(22.32)$ & $0.91(0.75-1.10)$ & 0.734 \\
\hline Takezaki T & 2002 & Chinese & Population based & Sex, age, ethnicity & $101(50.00)$ & $198(54.55)$ & $0.83(0.59-1.17)$ & 0.002 \\
\hline Hanaoka $\mathrm{T}^{\mathrm{a}}$ & 2001 & Brazil & Hospital-based & Sex, age, ethnicity & $58(40.52)$ & $127(43.30)$ & $0.89(0.57-1.39)$ & 0.250 \\
\hline Hanaoka $\mathrm{T}^{\mathrm{a}}$ & 2001 & Brazil & Hospital-based & Sex, age, ethnicity & $208(19.95)$ & $205(21.95)$ & $0.89(0.63-1.24)$ & 0.444 \\
\hline Tsukino H & 2004 & Japanese & Hospital-based & Sex, age ,residential area & $142(51.06)$ & $271(46.68)$ & $1.19(0.89-1.59)$ & 0.457 \\
\hline Palli D & 2010 & Italian & Population based & Frequency matching & $304(20.23)$ & $545(22.84)$ & $0.86(0.67-1.09)$ & 0.892 \\
\hline Farinati F & 2008 & Italian & Hospital-based & Frequency matching & $50(19.00)$ & $43(8.14)$ & $2.65(1.06-6.65)$ & 0.561 \\
\hline Sun LM & 2010 & Chinese & Hospital-based & Frequency matching & $73(58.22)$ & $255(48.43)$ & $1.48(1.02-2.15)$ & 0.294 \\
\hline Poplawski T & 2006 & Polish & Hospital-based & Sex, age & $28(10.71)$ & $33(22.73)$ & $0.41(0.15-1.14)$ & 0.091 \\
\hline Canbay E & 2010 & Turkey & volunteer & Sex, age & $40(23.75)$ & $247(16.80)$ & $1.54(0.88-2.72)$ & 0.990 \\
\hline Liu X & 2011 & Chinese & Hospital-based & Frequency matching & $618(57.12)$ & $913(59.75)$ & $0.90(0.78-1.52)$ & 0.589 \\
\hline Malik MA & 2010 & Indian & Hospital-based & Frequency matching & $108(30.09)$ & $195(28.97)$ & $1.06(0.58-0.97)$ & 0.121 \\
\hline
\end{tabular}

a The article Hanaoka et al., 2001 involved 2 different subgroups and was treated as two independent studies only in the subgroup analysis based on ethnicity. ${ }^{\mathrm{b}} \mathrm{HWE}$, Hardy-Weinberg equilibrium. 


\section{Results}

Study Characteristics. The detailed characteristics of the studies investigated the association of hOGG1 S326C polymorphisms with gastric cancer were shown in Table 1, the details for the study searching were shown in Figure 1.

There were 282 articles relevant to the search words (Pubmed 17, Elsivier Science Direct 252, Wanfang 3, CKNI 10, CBM 0), of which 262 articles were excluded and a total of 20 articles were identified through literature search and selection based on the inclusion criteria. Of these, 1 article was performed in vitro, 1 article used animals, 1 article was a review, 2 articles did not explore gastric cancer, and 1 article was not a case-control study. During the extraction of

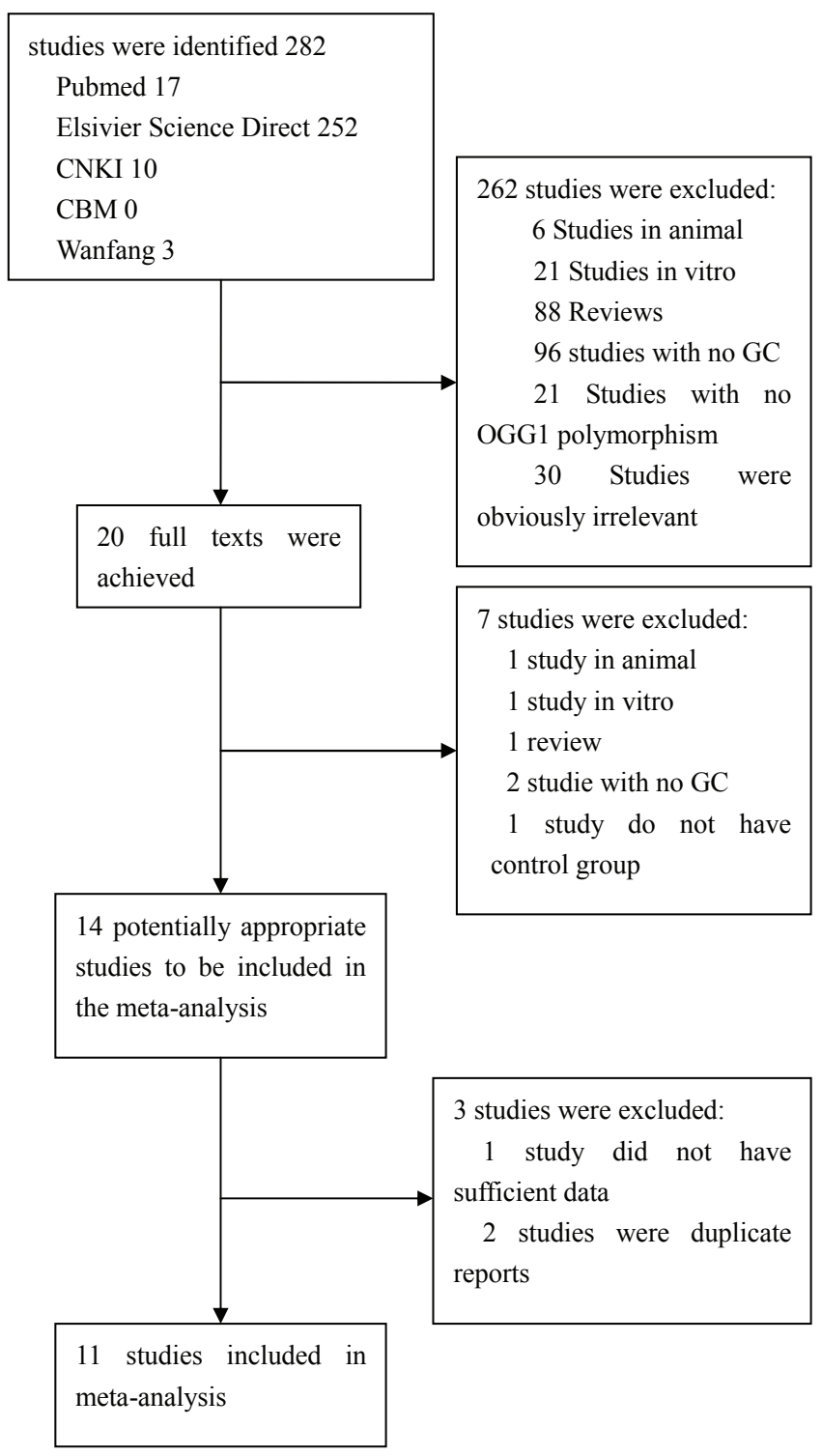

Figure 1. Flow diagram of the study selection process. data, 1 article was excluded owing to unavailable data [28], and 2 articles were excluded as they were duplicate reports. Thus, 11 studies were included in the current meta-analysis [29-39]. The study performed by Hanaoka et al. (2001) contained 2 different subpopulations, and was treated as 2 different studies.

The results of Hardy-Weinberg equilibrium test for the distribution of the genotype in control population are shown in Table 2. Among the 10 eligible studies included in the present meta-analysis, there was 1 study [37] which was not in Hardy-Weinberg equilibrium.

Association between hOGG1 S326C genetic polymorphism and gastric cancer risk. We included 2168 gastric cancer patients and 4058 control subjects in the final analysis. In the overall analysis, individuals carrying the hOGG1 GG genotype did not have significantly increased gastric cancer risk compared with those carrying the $\mathrm{CC}$ genotype $(\mathrm{OR}=$ 0.94, 95\% CI $=0.78-1.14, \mathrm{P}=0.517$ ) (Table 2). Similarly, no significant association with gastric cancer risk was found in either a recessive model $(\mathrm{OR}=1.07,95 \% \mathrm{CI}=0.82-1.38, \mathrm{P}=$ $0.635)$ and dominant model $(\mathrm{OR}=0.92,95 \% \mathrm{CI}=0.81-1.03$, $\mathrm{P}=0.141$ ) (Table 2, Figure 2).

Stratification analysis was further performed by the region to evaluate the effect of hOGG1 S326C polymorphism on the risk of gastric cancer. No significant association was found in Asian $(\mathrm{OR}=1.13,95 \% \mathrm{CI}=0.76-1.68, p=0.554$ for GG versus $\mathrm{CC}$; $\mathrm{OR}=1.23,95 \% \mathrm{CI}=0.83-1.83, p=0.301$ for GG versus $\mathrm{CG}+\mathrm{CC}, \mathrm{OR}=0.96,95 \% \mathrm{CI}=0.80-1.16, p=0.689$ for $\mathrm{GG}+\mathrm{CG}$ versus $\mathrm{CC}$ ) or European subgroup $(\mathrm{OR}=0.85$, $95 \% \mathrm{CI}=0.57-1.29, p=0.450$ for $\mathrm{GG}$ versus $\mathrm{CC} ; \mathrm{OR}=0.89$, $95 \% \mathrm{CI}=0.59-1.33, p=0.561$ for $\mathrm{GG}$ versus $\mathrm{CG}+\mathrm{CC}, \mathrm{OR}=$ $0.90,95 \% \mathrm{CI}=0.62-1.30, p=0.568$ for $\mathrm{GG}+\mathrm{CG}$ versus $\mathrm{CC}$ ) (Table 2, Figure 2). While in Brazilian subgroup, only 1 study with 2 subpopulations was included [30], and the results turned out that ther was no significant association between the polymorphism and gastric cancer risk $(\mathrm{OR}=0.81,95 \%$ $\mathrm{CI}=0.41-1.60, p=0.552$ for $\mathrm{GG}$ versus $\mathrm{CC} ; \mathrm{OR}=0.79,95 \%$ $\mathrm{CI}=0.42-1.48, p=0.459$ for $\mathrm{GG}$ versus $\mathrm{CG}+\mathrm{CC}, \mathrm{OR}=0.89$, $95 \% \mathrm{CI}=0.63-1.25, p=0.488$ for GG+CG versus CC) (Table 2, Figure 2). After excluding 1 study [37] involving Chinese population whose control had inconsistent genotype distribution with that of the Hardy-Weinberg equilibrium, no significant association was seen in any genetic model in overall analysis or Asian subgroup.

In further sensitivity analysis, we found that the ORs in the study performed by Tsukino et al. [34] and the study performed by Sun et al. [35] were significantly apart away from those of other studies. When these 2 studies were excluded, there was no evidence of heterogeneity in the quantitative analysis among Asians $\left(P_{\text {het }}=0.245\right.$ for GG versus CC; $P_{\text {het }}=$ 0.318 for $\mathrm{GG}+\mathrm{CG}$ versus $\mathrm{CC}$; $P_{\text {het }}=0.409$ for $\mathrm{GG}$ versus $\mathrm{CG}+\mathrm{CC})$.

Publication Bias. Both Begg's funnel plot and Egger's test were used to assess the publication bias in the present meta-analysis. In the funnel plot analysis, the shape of the 
Study

$$
\text { ID }
$$

$\%$

OR $(95 \% \mathrm{Cl}) \quad$ Weight

European

Capella G[32] Spain (2008)

Palli D[38] Italy (2010)

Farinati F[31] Italy (2008)

Poplawski T[36] Poland (2006)

Subtotal (l-squared $=0.0 \%, p=0.405$ )

Asian

Takezaki T[37] China (2002)

Tsukino H[34] Japan (2004)

Sun LM[35] China (2010)

Canbay E[33] Turkey (2010)

Liu X[29] China (2011)

Malik MA[39] India (2010)

Subtotal (l-squared $=67.1 \%, p=0.010)$

Brazilian

Hanaoka T1[30] Brazil (2001)

Hanaoka T2[30] Brazil (2001)

Subtotal (l-squared $=0.0 \%, p=0.576$ )

Overall (l-squared $=45.8 \%, p=0.048$ )

NOTE: Weights are from random effects analysis

A

Study

ID
$0.97(0.58,1.62) \quad 12.60$

$0.67(0.33,1.36) \quad 8.73$

$4.48(0.21,96.01) \quad 0.71$

(Excluded) $\quad 0.00$

$0.88(0.58,1.33) \quad 22.04$

$0.77(0.43,1.39) \quad 10.90$

$1.26(0.78,2.03) \quad 13.29$

$2.46(1.43,4.23) \quad 11.89$

$2.78(0.69,11.23) 3.07$

$0.89(0.72,1.11) \quad 20.72$

$1.06(0.40,2.77) \quad 5.66$

$1.23(0.83,1.83) \quad 65.54$

$0.68(0.30,1.56) \quad 7.07$

$0.99(0.36,2.68) \quad 5.35$

$0.79(0.42,1.50) \quad 12.42$

$1.07(0.82,1.38) \quad 100.00$

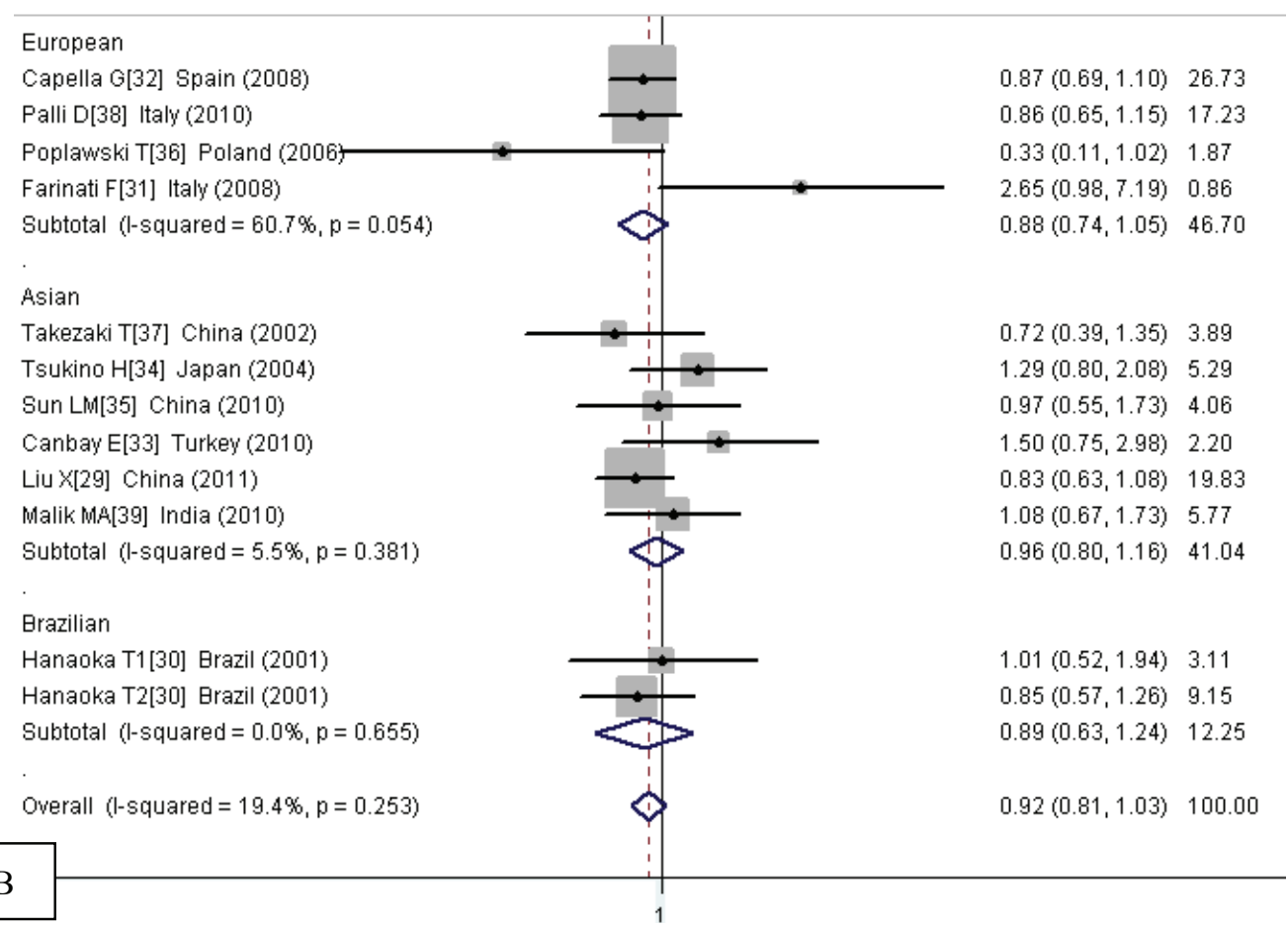

Figure 2. Forest plots of relationship between hOGG1 S326C polymorphism and risk of gastric cancer in recessive (A) or dominant (B) model. The size of the black square corresponding to each study is proportional to the sample size, and the center of each square represents of the OR. Horizontal line shows the corresponding 95\% CI of the OR. Pooled OR is represented by hollow diamonds and was obtained using fixed-or random- effect model. 

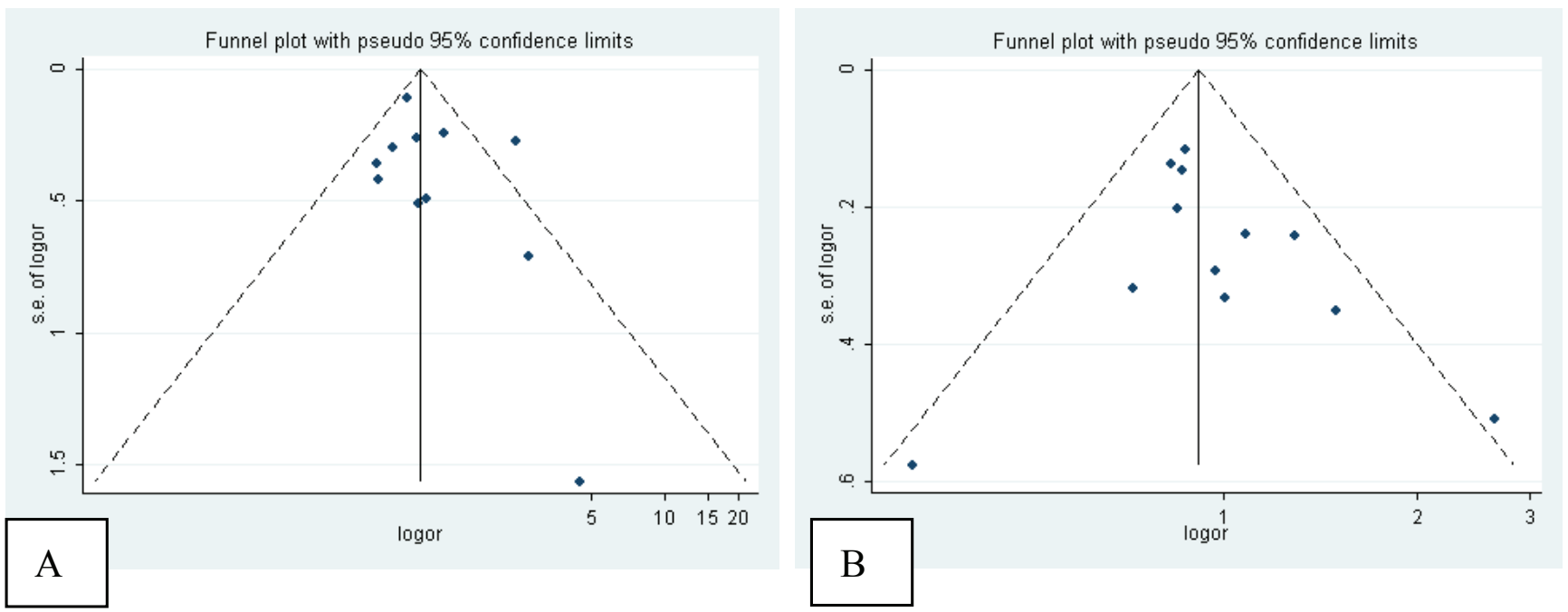

Figure 3. Funnel plots with pseudo $95 \%$ confidence limits for meta-analysis. (A) recessive model, (B) dominant model.

funnel plot seemed symmetrical (Figure 3). Furthermore, the Egger's test was used to provide statistical evidence of funnel plot symmetry. The results still did not suggest any obvious evidence of publication bias for all genetic models $(P=0.166$ for GG versus $C C ; P=0.333$ for $G G$ versus $C G+C C ; P=0.323$ for $\mathrm{GG}+\mathrm{CG}$ versus $\mathrm{CC}$ ).

\section{Disscussion}

Oxidative damage to DNA is continuously produced as a result of endogenous oxidative stress and exposure to chemical carcinogens. Among the many types of oxidative DNA damage, 8-OHdG residue is one of the most abundant oxidative products of cellular DNA, and is believed to be highly mutagenic because of its propensities to mispair with adenine during DNA replication and to cause ultimately GC to TA transversion [12-13]. Increase in $8-\mathrm{OHdG}$ content in DNA was shown to elevate cancer risk in several studies [40].

The human 8-oxoguanine glycosylase 1 (hOGG1) encoded by the hOGGI gene located on chromosome 3 is responsible for repairing 8-OHdG lesions, and is ubiquitously expressed in a variety of organs [41].

The hOGG1 gene is expressed as multiple alternatively spliced isoforms, and it is highly polymorphic [41]. The 1245 C $>$ G (S326C) polymorphism is a well known hOGG1 gene polymorphism, caused an amino substitution from serine to cystein in a codon 326 . Several studies have suggested that the hOGG1 S326C polymorphism may be associated with increased risks of several kinds of cancer.

Table 2 Meta-analysis of the association between the OGG1 S326C genetic polymorphism and the risk of gastric cancer

\begin{tabular}{|c|c|c|c|c|c|c|c|c|c|c|c|}
\hline \multirow[t]{2}{*}{ Polymorphism } & \multirow[t]{2}{*}{ Study } & \multicolumn{2}{|c|}{ Sample size } & \multirow{2}{*}{$\begin{array}{l}\text { No. of } \\
\text { studies }\end{array}$} & \multicolumn{4}{|c|}{ Test of association } & \multicolumn{3}{|c|}{ Test of heterogeneity } \\
\hline & & case & control & & OR $(95 \% \mathrm{CI})$ & $z$ & $P$-value & Model $^{*}$ & $x^{2}$ & $P$-value & $I^{2}(\%)$ \\
\hline \multirow[t]{4}{*}{ GG vs. CC } & Overall & 2140 & 4025 & 11 & $0.94(0.78-1.14)$ & 0.65 & 0.517 & $\mathrm{~F}$ & 13.42 & 0.201 & 25.5 \\
\hline & Asian & 1082 & 2079 & 6 & $1.13(0.76-1.68)$ & 0.59 & 0.554 & $\mathrm{R}$ & 10.62 & 0.059 & 52.9 \\
\hline & European & 792 & 1614 & 3 & $0.85(0.57-1.29)$ & 0.76 & 0.450 & $\mathrm{~F}$ & 2.10 & 0.351 & 4.5 \\
\hline & Brazilian & 266 & 332 & 2 & $0.81(0.41-1.60)$ & 0.60 & 0.552 & $\mathrm{~F}$ & 0.11 & 0.739 & 0.0 \\
\hline \multirow[t]{4}{*}{ GG vs. $\mathrm{GC}+\mathrm{CC}$} & Overall & 2140 & 4025 & 11 & $1.07(0.82-1.38)$ & 0.48 & 0.635 & $\mathrm{R}$ & 18.44 & 0.048 & 45.8 \\
\hline & Asian & 1082 & 2079 & 6 & $1.23(0.83-1.83)$ & 1.03 & 0.301 & $\mathrm{R}$ & 15.20 & 0.010 & 67.1 \\
\hline & European & 792 & 1614 & 3 & $0.89(0.59-1.33)$ & 0.58 & 0.561 & $\mathrm{~F}$ & 1.81 & 0.405 & 0.0 \\
\hline & Brazilian & 266 & 332 & 2 & $0.79(0.42-1.48)$ & 0.74 & 0.459 & $\mathrm{~F}$ & 0.31 & 0.576 & 0.0 \\
\hline \multirow[t]{4}{*}{ GG+GC vs. $C C$} & Overall & 2168 & 4058 & 12 & $0.92(0.81-1.03)$ & 1.47 & 0.141 & $\mathrm{~F}$ & 13.65 & 0.253 & 19.4 \\
\hline & Asian & 1082 & 2079 & 6 & $0.96(0.80-1.16)$ & 0.40 & 0.689 & $\mathrm{~F}$ & 5.29 & 0.381 & 5.5 \\
\hline & European & 820 & 1647 & 4 & $0.90(0.62-1.30)$ & 0.57 & 0.568 & $\mathrm{R}$ & 7.63 & 0.054 & 60.7 \\
\hline & Brazilian & 266 & 332 & 2 & $0.89(0.63-1.25)$ & 0.69 & 0.488 & $\mathrm{~F}$ & 0.20 & 0.655 & 0.0 \\
\hline
\end{tabular}

${ }^{\star}$ F: fixed-effect model; R: random-effect model 
The association of hOGG1 S326C genetic polymorphism with gastric cancer has been reported by a number of investigators. However, the conclusions remain controversial. In the present meta-analysis, we retrieved 11 studies (2168 Cases and 4058 controls) to evaluate the association of hOGG1 S326C genetic polymorphism with gastric cancer. Among these studies, 4 (820 Cases and 1647 controls) were performed involving Europeans[14,19], 6 studies (1082 cases and 2079 controls) were performed involving Asians, and the other study (266 Cases and 332 controls) with 2 subpopulations was performed involving Brazilians. As far as we know, this is the first meta-analysis carried out with the aim of investigating the relationship between hOGG1 S326C genetic polymorphism and gastric cancer.

Compared with the wild-type CC genotype, the variant GG homozygous genotype was not significantly associated with overall gastric cancer risk in the overall analysis in the present meta-analysis. Similarily, no statistical evidence of an overall effect of the S326C polymorphism on gastric cancer risk in either recessive or dominant model was found. In the stratified analysis by ethnicity, still no significant association was found between the polymorphism and gastric cancer risk in Asians, Europeans, and Brazilians. This is in accordance with the results from most of the studies included. This may be due to the fact that other polymorphisms of DNA repair genes involved in the repair of oxidative DNA damage may mask the disadvantage of the GG variant of the hOGG1 gene. On the other hand, life style and environmental factors such as $\mathrm{H}$. pylori infection, diet, and smoking may also contribute to the development of GC.

It is possible that hOGG1 S326C polymorphism plays differently in different gender. Thus a stratified analysis based on gender should be conducted. Unfortunately, of the 11 included studies, there was only 1 study providing detailed information on the genotype distribution of hOGG1 S326C in different gender. Therefore we could not conduct a stratified analysis based on gender in the present study.

There are some limitations inherent in this meta-analysis. First, significance between-study heterogeneity was detected, which may distort the meta-analysis. Second, all the studies included in the present study were published papers. It is possible that some relevant unpublished studies that may have met the inclusion criteria were missed. Thus, publication bias may exist in the results although neither the funnel plots nor Egger's linear regression tests indicated remarkable publication bias in the meta-analysis. Third, selection bias could have played a role because the genotype distribution of this polymorphism among control subjects deviated from the Hardy-Weinberg equilibrium in 1 study. Fourth, several studies had a relatively small sample sizes and included only one ethnic group. Fifth, in the subgroup analysis by ethnicity, only four studies were conducted in Europeans and only one study was conducted involving Brazilians. Therefore, to conduct a more precise analysis of this functional polymorphism on GC risk, addi- tional studies with large sample size and involving different ethnicities are warranted.

Despite the limitations, results of the present meta-analysis suggest that there was no significant association between the hOGG1 S326C genetic polymorphism and risk of gastric cancer. Further studies with large sample sizes including different ethnic groups with a careful matching between cases and controls are warranted to confirm our findings.

\section{References}

1] JEMAL A, BRAY F, CENTER MM, FERLAY J, WARD E, et al. Global cancer statistics. CA Cancer J Clin 2011; 61: 69-90. http://dx.doi.org/10.3322/caac.20107

[2] BROWN LM, DEVESA SS. Epidemiologic trends in esophageal and gastric cancer in the United States. Surg Oncol Clin N Am 2002; 11: 235-256. http://dx.doi.org/10.1016/S10553207(02)00002-9

[3] BAIK SC, YOUN HS, CHUNG MH, LEE WK, CHO MJ, et al. Increased oxidative DNA damage in Helicobacter pylori-infected human gastric mucosa. Cancer Res 1996; 56: 1279-1282.

[4] WITHERELL HL, HIATT RA, REPLOGLE M, PARSONNET J. Helicobacter pylori infection and urinary excretion of 8-hydroxy-2-deoxyguanosine, an oxidative DNA adduct. Cancer Epidemiol Biomarkers Prev 1998; 7: 91-96.

[5] TREDANIEL J, BOFFETTA P, BUIATTI E, SARACCI R, HIRSCH A. Tobacco smoking and gastric cancer: review and meta-analysis. Int J Cancer 1997; 72: 565-573. http://dx.doi. org/10.1002/(SICI)1097-0215(19970807)72:4<565::AIDIJC3>3.0.CO;2-O

[6] CORREA P. Human gastric carcinogenesis: a multistep and multifactorial process--First American Cancer Society Award Lecture on Cancer Epidemiology and Prevention. Cancer Res 1992; 52: 6735-6740.

[7] GLEI M, LATUNDE-DADA GO, KLINDER A, BECKER TW, HERMANN U, et al. Iron-overload induces oxidative DNA damage in the human colon carcinoma cell line HT29 clone 19A. Mutat Res 2002; 519: 151-161.

[8] MATYSIAK-BUDNIK T, MEGRAUD F. Helicobacter pylori infection and gastric cancer, Eur J Cancer 2006; 42: 708-716. http://dx.doi.org/10.1016/j.ejca.2006.01.020

[9] SINGH M, PRASAD KN, SAXENA A, YACHHA SK. Helicobacter pylori induces apoptosis of T- and B-cell lines and translocates mitochondrial apoptosis-inducing factor to nucleus. Curr Microbiol 2006; 52: 254-260. http://dx.doi. org/10.1007/s00284-005-0103-1

[10] YAMASAKI E, WADA A, KUMATORI A, NAKAGAWA I, FUNAO J, et al. Helicobacter pylori vacuolating cytotoxin induces activation of the proapoptotic proteinBax andBak, leading to cytochrome $\mathrm{c}$ release and cell death, independent of vacuolation. J Biol Chem 2006; 281: 11250-11259. http:// dx.doi.org/10.1074/jbc.M509404200

[11] DE LUCA A, IAQUINTO G. Iaquinto, Helicobacter pylori and gastric diseases: a dangerous association. Cancer Lett 2004; 213: 1-10. http://dx.doi.org/10.1016/j.canlet.2004.06.006 
[12] CHENG KC, CAHILL DS, KASAI H, NISHIMURA S, LOEB LA. 8- Hydroxyguanine, an abundant form of oxidative DNA damage, causes G----T and A----C substitutions. J Biol Chem 1992; 267: 166-172.

[13] HAZRA TK, HILL JW, IZUMI T, MITRA S. Multiple DNA glycosylases for repair of 8-oxoguanine and their potential in vivo functions. Prog Nucleic Acid Res Mol Biol 2001; 68: 193-205. http://dx.doi.org/10.1016/S0079-6603(01)68100$\underline{5}$

[14] BOITEUX S, RADICELLA JP. The human OGG1 gene: structure, functions, and its implication in the process of carcinogenesis. Arch Biochem Biophys 2000; 377: 1-8. http:// dx.doi.org/10.1006/abbi.2000.1773

[15] SUNAGA N, KOHNO T, SHINMURA K, SAITOH T, MATSUDA T, et al. OGG1 protein suppresses G:C--> T:A mutation in a shuttle vector containing 8-hydroxyguanine in human cells. Carcinogenesis 2001; 22: 1355-1362. http://dx.doi. org/10.1093/carcin/22.9.1355

[16] ROSENQUIST TA, ZHARKOV DO, GROLLMAN AP. Cloning and characterization of a mammalian 8-oxoguanine DNA glycosylase. Proc Natl Acad Sci USA. 1997; 94: 7429-7434. http://dx.doi.org/10.1073/pnas.94.14.7429

[17] KOHNO T, SHINMURA K, TOSAKA M, TANI M, KIM $\mathrm{SR}$, et al. Genetic polymorphisms and alternative splicing of the hOGG1 gene, that is involved in the repair of 8-hydroxyguanine in damaged DNA. Oncogene 1998; 16: 3219-3225. http://dx.doi.org/10.1038/sj.onc.1201872

[18] HARDIE LJ, BRIGGS JA, DAVIDSON LA, ALLAN JM, KING RF, et al. The effect of hOGG1 and glutathione peroxidase I genotypes and $3 p$ chromosomal loss on 8-hydroxy-deoxyguanosine levels in lung cancer. Carcinogenesis 2000; 21: 167-172. http://dx.doi.org/10.1093/carcin/21.2.167

[19] ELAHI A, ZHENG Z, PARK J, EYRING K, MCCAFFREY T, et al. The human OGG1 DNA repair enzyme and its association with orolaryngeal cancer risk. Carcinogenesis 2002; 23: 1229-1234. http://dx.doi.org/10.1093/carcin/23.7.1229

[20] ARIZONO K, OSADA Y, KURODA Y. DNA repair gene hOGG1 codon 326 and XRCC1 codon 399 polymorphisms and bladder cancer risk in a Japanese population. Jpn J Clin Oncol 2008; 38: 186-191. http://dx.doi.org/10.1093/jico/ $\underline{\text { hym } 176}$

[21] JIAO X, HUANG J, WU S, LV M, HU Y, et al. hOGG1 Ser326Cys polymorphism and susceptibility to gallbladder cancer in a Chinese population. Int J Cancer 2007; 121: 501505. http://dx.doi.org/10.1002/ijc.22748

[22] COCHRAN WG. The combination of estimates from different experiments. Biometrics 1954; 10: 101-129. http://dx.doi. org/10.2307/3001666

[23] MANTEL N, HAENSZEL W. Statistical aspects of the analysis of data from retrospective studies of disease. J Natl Cancer Inst 1959; 22: 719-748.

[24] DERSIMONIAN R, LAIRD N. Meta-analysis in clinical trials. Control Clin Trials 1986; 7: 177-188. http://dx.doi. org/10.1016/0197-2456(86)90046-2

[25] HIGGINS JP, THOMPSON SG, DEEKS JJ, ALTMAN DG. Measuring inconsistency in meta-analyses. Br Med J. 2003; 327: 557-560. http://dx.doi.org/10.1136/bmj.327.7414.557
[26] EGGER M, DAVEY SMITH G, SCHNEIDER M, MINDER C. Bias in meta-analysis detected by a simple, graphical test. Br Med J 1997; 315: 629-634. http://dx.doi.org/10.1136/ bmj.315.7109.629

[27] BEGG CB, BERLIN JA. Publication bisa: a problem in interpreting medical data. J R Statist Soc A 1988; 151: 419-463. http://dx.doi.org/10.2307/2982993

[28] GARCIA-GONZALEZ MA, QUINTERO E, BUJANDA L, NICOLÁS-PÉREZ D, BENITO R, et al. Relevance of DNA Repair Gene Polymorphisms on Gastric Cancer Susceptibility and Phenotype. Gastroenterology 2011; 140 :S354.

[29] LIU X, XIAO N, GUO W, WU Y, CAI Z, et al. The hOGG1 gene 5 '-UTR variant c.-53G>C contributes to the risk of gastric cancer but not colorectal cancer in the Chinese population: The functional variation of hOGG1 for gastric cancer risk. J Cancer Res Clin Oncol 2011; 137: 1477-1485. http://dx.doi. org/10.1007/s00432-011-1022-0

[30] HANAOKA T, SUGIMURA H, NAGURA K, IHARA M, LI $\mathrm{XJ}$, et al. hOGG1 exon7 polymorphism and gastric cancer in case-control studies of Japanese Brazilians and non-Japanese Brazilians. Cancer Lett 2001; 170: 53-61. http://dx.doi. org/10.1016/S0304-3835(01)00565-1

[31] FARINATI F, CARDIN R, BORTOLAMI M, NITTI D, BASSO $\mathrm{D}$, et al. Oxidative DNA damage in gastric cancer: CagA status and OGG1 gene polymorphism. Int J Cancer 2008; 123: 51-55. http://dx.doi.org/10.1002/ijc.23473

[32] CAPELla G, PERA G, SALA N, AGUDO A, RICO F, et al. DNA repair polymorphisms and the risk of stomach adenocarcinoma and severe chronic gastritis in the EPIC-EURGAST study. Int J Epidemiol 2008; 37: 1316-1325. http://dx.doi. org/10.1093/ije/dyn145

[33] CANBAY E, AGACHAN B, GULLUOGLU M, ISBIR T, BALIK E, et al. Possible associations of APE1 polymorphism with susceptibility and HOGG1 polymorphism with prognosis in gastric cancer. Anticancer Res 2010; 30: 1359-1364.

[34] TSUKINO H, HANAOKA T, OTANI T, IWASAKI M, KOBAYASHI M, et al. hOGG1 Ser326Cys polymorphism, interaction with environmental exposures, and gastric cancer risk in Japanese populations. Cancer Sci 2004; 95: 977-983. http://dx.doi.org/10.1111/j.1349-7006.2004. tb03186.x

[35] SUN LM, SHANG Y, ZENG YM, DENG YY, CHENG JF. HOGG1 polymorphism in atrophic gastritis and gastric cancer after Helicobacter pylori eradication. World J Gastroenterol 2010; 16: 4476-4482. http://dx.doi.org/10.3748/wig. v16.i35.4476

[36] POPLAWSKI T, ARABSKI M, KOZIROWSKA D, BLASINSKA-MORAWIEC M, MORAWIEC Z, et al. DNA damage and repair in gastric cancer--a correlation with the hOGG1 and RAD51 genes polymorphisms. Mutat Res 2006; 601: 83-91. http://dx.doi.org/10.1016/j.mrfmmm.2006.06.002

[37] TAKEZAKI T, GAO CM, WU JZ, LI ZY, WANG JD, et al. hOGG1 Ser(326)Cys polymorphism and modification by environmental factors of stomach cancer risk in Chinese. Int J Cancer 2002; 99: 624-627. http://dx.doi.org/10.1002/ ijc. 10400 
[38] PALLI D, POLIDORO S, D'ERRICO M, SAIEVA C, GUARRERA S, et al. Polymorphic DNA repair and metabolic genes: a multigenic study on gastric cancer. Mutagenesis 2010; 25:569575. http://dx.doi.org/10.1093/mutage/geq042

[39] MALIK MA, ZARGAR SA, MITTAL B. Lack of influence of DNA repair gene OGG1 codon 326 polymorphisms of gastric cancer risk in the Kashmir valley. Asian Pac J Cancer Prev 2010;11: 165-168.
[40] GREIM H, CSANADY G, FILSER JG, KREUZER P, SCHWARZ L, et al. Biomarkers as tools in human health risk assessment. Clin Chem 1995; 41: 1804-1808.

[41] NISHIOKA K, OHTSUBO T, ODA H, FUJIWARA T, KANG $\mathrm{D}$, et al. Expression and differential intracellular localization of two major forms of human 8-oxoguanine DNA glycosylase encoded by alternatively spliced OGG1 mRNAs. Mol Biol Cell 1999; 10: 1637-1652. 